Maria Tsima*

ORCID: 0000-0003-2784-7941

University of Wrocław

DOI: $10.19195 / 1733-5779.29 .4$

\title{
Between consensus and the "tax agreement" provided for in the draft of the Tax Ordinance of June 4, 2019
}

\section{JEL Classification: K34}

Keywords: tax ordinance, tax agreement, public law, private law

Słowa kluczowe: ordynacja podatkowa, umowa podatkowa, prawo publiczne, prawo prywatne

Abstract: A change in the perception of the relationship between the tax debtor and the tax creditor is necessary. The regulation of non-governing forms of operation of tax authorities is the normative basis that determines the change in the way in which tax matters are dealt with. This article reviews the proposal for consensual resolution of disputes contained in the draft of the Tax Ordinance of March 8, 2019. In this draft, a chapter entitled "Tax agreement" was included, which is devoted entirely to the structure of the tax agreement. However, to what extent does the outlined legal structure of the tax agreement make it possible to create a negotiating space between the taxpayer and the tax authority? The consensuality that the parties strive for should foster the pursuit of the private interest in the optimal dimension and, at the same time, should not affect the public interest. This is possible. In this way, the equality of parties manifests itself in the framework of consumer contracts (where the entrepreneur's party is stronger) or on the level of repressive law (for example, in criminal law - where, as indicated, the consensual way of settling the matter should not disqualify the aspiration to equalize the position of all participants of this consensus). The position defended by the present author is that obtaining a contractual agreement in tax law based on a consensus assuming the parity of parties does not exclude the possibility of pursuing a fiscal interest.

\section{Między konsensusem a „umową podatkową" przewidzianą projektem Ordynacji Podatkowej z dnia 4 czerwca 2019 roku}

Abstrakt: Konieczna jest zmiana postrzegania relacji dłużnik podatkowy-wierzyciel podatkowy. Regulacja niewładczych form działania organów podatkowych stanowi bowiem podstawę nor-

* Scientific Tutor (Opiekun naukowy) — prof. dr hab. Paweł Borszowski 
matywną warunkującą przeprowadzenie zmiany sposobu załatwiania spraw podatkowych. W artykule analizie poddano propozycję konsensualnego rozwiązywania sporów podatkowych zawartą w projekcie Ordynacji podatkowej z 8 marca 2019 roku. W projekcie tym ujęto rozdział poświęcony w całości konstrukcji umowy podatkowej. Na ile jednak zarysowana konstrukcja prawna umowy podatkowej umożliwia zaistnienie przestrzeni negocjacyjnej między podatnikiem a organem podatkowym? Warto, by konsensualność, do której dążyłyby strony takiej umowy, sprzyjała realizacji interesu prywatnego $\mathrm{w}$ wymiarze optymalnym i jednocześnie nie godziła $\mathrm{w}$ interes publiczny. Jest to możliwe. W taki sposób równość stron przejawia się w ramach umów konsumenckich (w których strona przedsiębiorcy jest wyjściowo stroną silniejszą) czy na płaszczyźnie prawa represyjnego (przykładowo w prawie karnym — gdzie jak się wskazuje, konsensualny sposób załatwienia sprawy nie powinien dyskwalifikować dążenia do zrównywania pozycji wszystkich uczestników tego konsensu). Autorka niniejszego artykułu broni stanowiska, że uzyskanie w podatkach umownego uzgodnienia na podstawie konsensusu zakładającego równorzędność stron nie wyklucza możliwości realizacji interesu fiskalnego.

\section{Introduction}

The division into public law and private law is up to date. ${ }^{1}$ There is no doubt in the doctrine that tax law, as a set of norms subordinated to the protection of public or social interest, should be classified as a category of public law. ${ }^{2}$ However, today there is a progressive blurring of the boundaries between the various branches of law. ${ }^{3}$ The process of adopting the legal institutions typical of civil law to the broadly understood public law is evolving. Hence, it is not possible to assign a specific branch of law with the character of "pure" private or public law. ${ }^{4}$ Moreover, due to the different functions and objects of the impact of specific branches of law, striving for a complete unification of their tools for shaping social relations seems to be pointless. ${ }^{5}$

The development of law outlined like this is assessed positively by the doctrine. ${ }^{6}$ Despite this, attention should be paid to the dangers ${ }^{7}$ accompanying the introduction of a measure or means of influencing social relations formed at the level of

${ }^{1}$ J. Nowacki, Public Law - Private Law, Katowice 1992, p. 8.

2 A. Mariański, Resolving Doubts in Favour of the Taxpayer: The Principle of Tax Law, Warszawa 2010, p. 13.

3 The branch of law is a complex of norms regulating social relations of one kind - L. Morawski, Introduction to Jurisprudence, Toruń 1998, p. 85.

${ }^{4}$ Ibidem, p. 93.

5 A. Nita, Agreement in Tax Law, Warszawa 2014, p. 35.

${ }^{6}$ In order to increase the effectiveness of the law, the legislator should take into account within the given branch of law both governing and non-governing activities (agreement, dialogue). So in: A. Nita, op. cit., p. 35, as well as L. Morawski, "The dispute over the model of legal policy - a systemic approach," Państwo i Prawo 1992, no. 9.

7 The term „danger" was used deliberately in the article, which according to the definition of the PWN dictionary should be understood as "a state, situation, location threatening someone" — https:// www.pwn.pl/ (accessed: 10.10.2019). Also in: A. Nita, op. cit., p. 35. 
another branch of law into the legal branch, stemming from a separate legal system. ${ }^{8}$ Each legal system is assigned, according to the normative content of the concept of legal sources, validation rules specific for this system, rules for the exegesis of law-making facts, and finally collision rules. ${ }^{9}$ The above decides that the legal nor constituted on the basis of a given branch of law will always be a consequence of the adopted validation rules, rules of exegesis and collisions rules.

Below, the proposal for consensual resolution of disputes contained in the draft of the Tax Ordinance of 4 June 2019 will be reviewed ${ }^{10}$ (hereinafter referred to as: Tax Ordinance draft). In this Tax Ordinance draft of 4 June 2019, a chapter was placed - entitled "Tax Agreement," which was entirely devoted to the title structure of the tax agreement. The authors of the Tax Ordinance draft at the outset clearly underline that the proposed legal structure, although it concerns a consensual method of solving tax cases (i.e. methods characteristic of civil law), should in no case be identified with a contract within the meaning of the Civil Code. ${ }^{11}$ Therefore, it cannot (according to what the authors of the draft point to) be predicted that the relationship between the taxpayer and the tax authority will be characterized by "parties' equality" or "equivalence of benefits."

Therefore a question arises, to what extent will it be possible to solve tax issues in a consensual manner within the proposed "tax agreement" assuming the absence of any equivalence of parties to such a settlement? The article presented below will attempt to defend a position, according to which obtaining a contractual agreement in tax law based on a consensus assuming (though to a minimum extent) parity of parties does not exclude the possibility of pursuing a fiscal interest.

\section{Construction of the "tax agreement"}

The tax relationship results not from the will of the subject of the legal tax relations, but only from the act. The actual tax status of the tax ordinance is the equivalent of the autonomy of the will of the parties to the civil law relationship. ${ }^{12}$ The taxpayer acts as a party to a specific tax-law relationship in the event of the update of the facts ascertained in individual tax acts. ${ }^{13}$ Such a formula is dictated by the factual difference of tax liabilities laid down in tax acts. ${ }^{14}$ The tax authority acts as a representative of the public interest in a tax-related relationship, with a privileged position. We are dealing here with a distinction characteristic of the

${ }^{8}$ The division into public law and private law is important in the process of establishing and applying the legal provisions of these two parts of the law, including tax law - A. Mariański, op. cit., p. 13.

${ }^{9}$ Z. Ziembiński, Basic Problems of Legal Studies, Warszawa 1980, p. 247.

${ }^{10}$ Draft of June 4, 2019 of Tax Ordinance (Print no. 3517) - the content of the draft is available on the ministerial websites — access protocol: http://sejm.gov.pl/Sejm8.nsf/druk.xsp?nr=3517 (accessed: 10.10.2019).

${ }^{11}$ The Act of April 23, 1964 The Civil Code (Journal of Laws of 2018, 1025, i.e. of 2018.05.29).

12 R. Mastalski, Tax Law, Warszawa 2016, p. 216.

13 Ibidem, p. 223.

14 P. Borszowski, Elements of the Legal Relationship of Tax Liability, Kraków 2004, p. 129. 
entire tax law of the parties to the authorized tax relationship and the obliged party. ${ }^{15}$ However, it must be borne in mind that representation of public interest must always take place within the limits set out in the Act. The tax authority is obliged to act not so much in accordance with the law as to exactly what the law requires. Its functioning is to constitute a kind of "legal tracing," as completely shaped by laws. It is possible here to indicate the existence of some kind of equivalent legal situation of entities of the obligatory relationship in tax law. ${ }^{16}$

This is how the relationship between the parties to a tax-law relationship is currently regulated. Since the "tax agreement" is supposed to be a consensual way of resolving disputes, then - at least on the procedural level of tax law - there is a chance to shape the relations of the parties to the "tax agreement" in a way closer to the civilian specificity.

Presentation of the "tax agreement" regulations should start with the content of Art. $411 \S 1$ of the Tax Ordinance draft, according to which the tax authority and the party may, after making arrangements, conclude a tax agreement. The originator in the above-mentioned provisions indicates that a "tax agreement" would be concluded between the tax authority and the party. Possible doubts as to whether the taxable person could only be the party to the "tax agreement" (i.e. a person of an existing tax-law relationship) is dispelled by the comment made by the co-authors of the Ordinance draft. This comment clearly states that: "the draft provision on a tax agreement, because it is incorporated into tax law, should be understood as a competence standard that allows the tax authorities to enter into an agreement with the tax debtor." ${ }^{\prime 17}$ This is connected with the fact that in the tax proceedings, the procedure is the original way of concluding the tax claim. ${ }^{18}$ The tax debtor, as an entity against whom a tax claim has been updated, is also the entity to which the taxable facts of the actual state have been fulfilled. ${ }^{19}$ The occurrence of a factual situation corresponding to the hypothesis of the tax law norm is the moment of the occurrence of a specific tax relation, under which the obliged entity is not an authorized entity, while the authorized entity is not an obliged entity. ${ }^{20}$

Therefore, it should be noted that in civil law and tax law we have a different moment of concretization of a claim arising from a civil and tax liability, but also different entities entitled to this concretization. On the level of tax law, it is possible to concretize a claim by one party of the tax relationship, somehow within that relationship. It can be assumed that the tax agreement is a meta-contract

${ }^{15}$ Ibidem, p. 82.

16 R. Mastalski, op. cit., p. 224.

${ }^{17}$ L. Etel (ed.), Tax Ordinance: Directional Assumptions of the New Regulation, Białystok 2015, p. 73.

18 Ibidem, p. 12.

19 P. Borszowski, op. cit., p. 83.

${ }^{20}$ R. Mastalski, op. cit., p. 21. 
(referring to a civil law approach), which does not create a new legal relationship, but refers to the existing tax-law relation. The updating of the tax dispute leads, consequently, to the necessity of determining "whether and to what extent the actual state contains the features of the legal and tax status of the facts." 21 The dispute arises when the taxpayer's initial determination of the tax claim proves to be unreliable.

Moving to the subject scope of the analyzed "tax agreement" now - according to Art. $411 \S 3$ of the Tax Ordinance draft, the "tax agreement" cannot rely on direct findings as to the amount of the tax or refer to the premises for stating tax avoidance. The subject of the arrangements between the tax authority and the obliged entity cannot constitute "bargaining" of the tax amount. At the same time, pursuant to Art. $412 \S 2$ of the Ordinance draft, before the conclusion of the tax agreement, the tax authority may ask the Head of the National Tax Administration for an opinion on the legitimacy of concluding such an agreement.

In the Tax Ordinance draft of 4 July $2018^{22}$ (no longer up-to-date), the wording was also predicted (Art. $380 \S 3$ ):

the tax agreement may consist in reciprocal concessions and is concluded within the limits of the law by acceptance of arrangements by the tax authority and the party [...]. In the justification to the previous version of the draft, it was pointed out that "the essence of the tax agreement is a consensus - consent between the parties, and not a compromise - a consent based on mutual concessions." 23

These "mutual concessions" between the tax authority and the taxpayer should not be treated as a manifestation of the desire to obtain the equivalence of benefits under the "tax agreement." In the latest version of the Tax Ordinance draft, the above-mentioned provision was abandoned.

The "tax agreement" will be able to be used only as part of the evidentiary proceedings and implemented through the adoption of the arrangements by the tax authority and the party, in particular:

1) in case of doubts as to the actual state of the case, including when their removal in the proceedings would involve excessive difficulties or costs disproportionate to the result;

2) regarding the nature or value of the transaction, activity or event;

3 ) in the application of reductions in the payment of taxes, in particular the type of reduction to be applied and the method of its application;

4) with regard to individual issues arising in the course of tax proceedings;

5) when a special provision so provides.

${ }^{21}$ Ibidem, p. 311.

22 Draft of 4.07 .2018 of the Tax Ordinance - the content of the draft is available on ministerial websites — access protocol: https://legislacja.rcl.gov.pl/projekt/12314054/katalog/12523374\#12523374 (accessed: 10.10.2019).

${ }^{23}$ Justification of the draft of the act - Tax Ordinance of 4.07.2018 - content of the justification available on the ministerial websites — access protocol: https://legislacja.rcl.gov.pl/projekt/12314054/ katalog/12523374\#12523374 (accessed: 10.10.2019). 
According to the above, the scope of the "tax agreement" would be formulated in the form of an open catalog. It would constitute a "negotiating space" between the tax authority and the taxpayer constituted with a legal regulation. ${ }^{24}$

Therefore, to what extent the outlined legal structure of the "tax agreement" makes it possible to create a negotiating space between the taxpayer and the tax authority? Establishment of every legal relationship between at least two legal entities is strictly dependent on the existence of specific legal norms that provide for the emergence of a specific type of relationship (socially desirable) between legal entities. There are legal relationships fully determined by law and those that are shaped by standards in a limited scope. The legal relationship determined only partly by the norm is indicated as a characteristic type of legal relationship. ${ }^{25}$ As part of such an incomplete relationship on the level of "legal norm - obligatory relationship," an unshaped range of relations formulated by entities forming this relationship may take place. As indicated by the authors of the Tax Ordinance draft in the justification for the draft - the negotiation space (space of talks and arrangements) between the taxpayer and the tax authority is opened not only in matters resolved in the so-called administrative recognition (e.g., in case of tax payment reliefs). Although, in practice, not every case is amenable to arbitration, however, with regard to more complex cases, it is impossible to predict in advance - in which it will be possible to conclude a contract under a lawful act and in which it is not appropriate to introduce a closed catalog of such matters. ${ }^{26}$

As can be seen, the authors of the project perceive a situation in which it would be possible to include the subject scope of the "tax agreement" into a specific numerus clausus.

\section{3. "Administrative agreement" as the model of the "tax agreement"}

In the justification for the Tax Ordinance draft, it was emphasized that the name of the "tax agreement" refers to the "administrative agreement" which was to be adopted as a result of the amendment to the administrative procedure code ${ }^{27}$ (hereinafter referred to, interchangeably, as: APC). Therefore, it seems justified in order to better understand the structure of the "tax agreement" - to confront its shape with the construction of the "administrative agreement." A comparison of these two proposals of legal constructions will make it possible to establish not how much the solutions have in common, but what is more important (against the

${ }^{24}$ L. Etel (ed.), op. cit., p. 3.

25 Ibidem, p. 16.

${ }^{26}$ Justification of the Act draft - Tax Ordinance of 7.03.2019 — the content of the justification available on the ministerial websites - access protocol: https://legislacja.rcl.gov.pl/projekt/12314054/ katalog/12523416\#12523416 (accessed: 10.10.2019).

27 The Act of June 14, 1960 the Code of Administrative Procedure (Journal of Laws of 2018, 2096 i.e. of 2018.11.05). 
background of the deliberations,) how the authors of the draft of the act amending the APC as part of the "administrative agreement" referred to the consensual nature of the "administrative agreement" assuming the lack of equality of parties to such a legal relationship.

The "administrative agreement" has been functioning on the level of doctrinal considerations of administrative law for a long time. This is related to the fact that transformations that take place in the socio-economic system of the country and the changes in the public administration system themselves call into question the dominance of unilateral forms of administration. ${ }^{28}$ Ultimately, however, all considerations are of an abstract nature. Since such a legal form of administration has not entered into force, considerations about its characteristics must be abstract. ${ }^{29}$ The subject construction is provided for in the draft law amending the APC of 4 July $2016^{30}$ (hereinafter interchangeably as: act draft amending the APC), the provisions of which in the scope of "administrative agreement" do not apply. On 1 June 2017 the Act of 7 April 2017 amending the Act - Code of Administrative Procedure and some other acts came into force. ${ }^{31}$

The "administrative agreement" was to constitute a new form of administrative matters, the essence of which was to settle the case by agreeing the matter by the public administrative authority with the party to the proceedings, or else jointly working out the resolution of the case. ${ }^{32}$

In the opinion issued to the draft of the APC amendment, attention was paid to the wording proposed in Art. 113a, a provision providing for the possibility of making "mutual concessions regarding the findings of a factual or legal state" in the "administrative agreement." This formulation was indicated as raising doubts as to the constitutional and systemic nature. Such a provision would - in the view of the authors of the opinion - increase the risk of occurrence of circumvention of the applicable law. As has already been pointed out - in the current wording of the Tax Ordinance draft in the part concerning the "tax agreement," there is no wording of the "mutual concessions." It can be suspected that not without reason, this type of entry was not included in the Tax Ordinance draft and that, at least, the concerns of the authors of the Act amending the APC were partially duplicated. All the more so because the Tax Ordinance draft of 4 July 2018 (no longer up-to-date) also provided that: "The tax agreement may involve mutual

${ }^{28}$ L. Zacharenko, "Administrative agreement (public law contract)," [in:] Administration: Administrative Law. General Part, eds. J. Blicharz, L. Zacharenko, Katowice 2018, p. 205.

29 J. Zimmermann, Axioms of Administrative Law, Warszawa 2013, p. 146.

30 Draft of July 4, 2016 of the Act amending the Act - Code of Administrative Procedure and some other acts - the content of the draft is available on the ministerial websites - access protocol: https://legislacja.rcl.gov.pl/projekt/12287313/katalog/12363091 (accessed: 10.10.2019).

31 The Act of April 7, 2017 amending the Act - Code of Administrative Procedure (Journal of Laws of 2017, 935 i.e. of 2017.05.12).

32 Ibidem. 
concessions and is concluded within the limits of the law by acceptance of the arrangements by the tax authority and the part, in particular."

The authority was to rule on the conclusion of an "administrative agreement" in accordance with the provisions of the draft of the act amending the APC. At the same time, this regulation obligated the public administration authority to indicate in the negative decision issued on the conclusion of an "administrative agreement" the factual and legal circumstances that constitute grounds for refusal to conclude this agreement (Art. 113e $\S 3$ of the Act amending the APC). The administrative proceedings are structured as inquisitorial proceedings, in which the governing body has a superordinate position over the party. ${ }^{33}$ And still, moving on the subject of introducing a consensual dispute resolution mechanism, one can notice that the need for non-arbitrary action is observed. In the opinion of 16 September 2016 issued in relation to the draft of amending the APC, the proposition of the wording of the provision of Art. 113e $\S 3$ of the draft of the Act amending the APC was criticized due to the lack of specification in this regulation of detailed premises that would condition or determine the possibility of the authority to refuse to conclude the agreement. Moreover, it was alleged that the establishment of such a record would be tantamount to a violation of the principle of specificity.

At this point, it is worth paying attention to the fact that the Tax Ordinance draft does not contain information on the justification of the negative decision regarding the conclusion of a "tax agreement." This should raise doubts. In the opinion of the authors of the Tax Ordinance draft, in both configurations, the tax agreement would have a consensual nature for both entities related to it. The above statement raises doubts. Finally, the tax authority enjoys a privileged position, so it seems reasonable to say that in this case, we will not have to deal, if not with the failure to implement a consensual model of dispute resolution, then certainly with its serious limitation. The question regarding the risk of violation of the principle of specificity is also updated.

In addition, in the justification of the draft of the act amending the APC, it was noted that the introduction of an "administrative agreement" into the administrative law would not infringe the essence of administrative matters by the authority through a ruling action, and the consensual nature of the agreement would primarily have a procedural dimension. Therefore, the need to preserve the privileged position of a public authority was also indicated here, at least in the non-process dimension.

The "administrative agreement" is known to many legal systems (for example, you can refer to Greek law, German law, French law, Spanish law, Portuguese law, Italian law or Finnish law). ${ }^{34}$ German regulations are considered a model for the

${ }^{33}$ L. Żukowski, [in:] L. Żukowski, R. Sawuła, Administrative Proceedings and Proceedings Before the Supreme Administrative Court, Warszawa 2002, p. 55.

34 P. Ostojski, Instrumentalization of the Law on Administrative Proceedings, Poznań 2017, p. 84. 
regulation of a typical "administrative agreement," according to which at the time of conclusion of the "administrative agreement" the superior entity somehow resigns from its privileged position. ${ }^{35}$ In spite of everything, in German regulations it is also noticed that since parties holding such a contract are constantly circulating within the public law, it is very difficult to create conditions that would place both parties to an administrative agreement" in an identical position. ${ }^{36}$

Thus, we can see that in the doctrine of administrative law (both domestic and foreign) positions that opt for the introduction of the equality principle to the widest extent possible in the public authority — private entity relations are formed. In Poland - considering that the "administrative agreement" has not come into force - the approach is still dominant, which consequently leads to the fact that "the postulate of equality defining the idea of democratization of administrative proceedings is pushed to the background by the requirements of effective operation. The security function of the administration gives way to the construction function." 37

\section{Consensus without the equality of the parties - is this a prospective step?}

Can a consensus that excludes any equality of the parties be effective? In the justification of the Tax Ordinance draft, it was emphasized that features such as equality of parties or the equivalence of benefits should not be attributed to the "tax agreement" construction. Despite this, it is explained successively that a "tax agreement" would have the value of a consensual solution.

This subject structure is to concern the "consensual (based on an agreement) way of settling tax matters by concluding a tax agreement between taxpayers and tax authorities. ${ }^{38}$ So this consensual dimension of the "tax agreement" would be to settle matters on the basis of agreement between parties to the agreement. According to the PWN dictionary, the word "agreement" can be treated as equivalent to phrases such as "consent to something" or "mutual understanding." 39

Despite the fact that the authors of the Tax Ordinance draft stipulate that one should not seek references or points of contact with a civil law agreement in the proposed structure of a "tax agreement," it is not at all possible to refer to the connection between consensuality and the equality of parties occurring within the civil law relations.

35 J. Zimmermann, op. cit., p. 146.

36 Ibidem.

37 Z. Cieślik, Administrative Agreement in the State of Law, Kraków 2007, p. 43.

38 Justification of the act draft — Tax Ordinance of 7.03.2019 — the content of opinions is available on the ministerial websites — access protocol: https://legislacja.rcl.gov.pl/projekt/12314054/kata$\log / 12523416 \# 12523416$ (accessed: 10.10.2019).

39 Ibidem. 
There is no legal definition of the term of an agreement in Polish legislation. The doctrine has, however, developed a universally accepted definition of an agreement as a legal act in which at least two parties are required and a consistent declaration of will of each of these parties is required. ${ }^{40}$ The provision of Art. $353 \S 1$ of the civil code defines an obligation as a legal relationship where one person (creditor) is entitled to demand fulfillment of the benefit, while the other (debtor) is obliged to perform the service. ${ }^{41}$ In the light of Art. $353^{1}$ of the civil code, the most important are the limits of freedom of agreements set by the Act, the principles of social coexistence and the property (nature) of the legal relationship. ${ }^{42}$ An agreement in the scope which limits the freedom of one party's economic activity, if it is no longer inconsistent with the law for other reasons, violates the general clause of the principles of social coexistence and is thus void (Art. $58 \S 2$ of the civil code). ${ }^{43}$ Entities that make decisions on the conclusion of an agreement within the meaning of civil law have the freedom to shape the content of the agreement. Accordingly, if the parties do not find it beneficial to implement their particular interests by agreeing on the content of the agreement, it is possible to decide not to conclude the agreement. At the plane of civil law, this mutual understanding consists, in principle, in balancing the will of both sides of the civil law relationship. The voluntary and consensual aspect, that is, consistent statements of the will of the people concluding the agreement, is something that characterizes contractual obligation relationships. ${ }^{44}$ Therefore, there is no doubt that the consensuality of legal acts is the rule. However, there are exceptions or rather special cases even from this rule also in civil law.

It should be noted here that the civil legal relationship constituting the implication of the concluded agreement is rarely able to fully meet the requirement of consistent statements of equal parties. Although the view of some representatives of the doctrine that the agreement came into effect "not by a consistent statement of two or more parties, but as a result of the party joining or an economically weaker party giving in to a model established by an economically stronger entrepreneur on the market" is accepted. ${ }^{45}$ The occurrence of borderline cases of consensus of the parties to the agreement is not possible to reconcile with the normative conception of agreement templates. ${ }^{46}$ However, it turns out that the autonomy of the will of the parties when concluding civil law agreements is not unlimited. It is possible to indicate situations when, within the framework of a specific civil

${ }^{40}$ Z. Radwański, Theory of Contracts, Warszawa 1977, p. 62.

41 Judgment of the Supreme Court of June 28, 2017, IV CSK 511/16, LEX 2360534.

42 Ibidem.

43 Judgment of the Supreme Court of June 24, 2014, I CSK 431/13, LEX 1511100.

44 Judgment of the Supreme Court (until 2003.12.31) in Szczecin of June 6, 2001, SA/Sz 511/00, LEX 1693828.

${ }^{45}$ Z. Radwański, op. cit., p. 92.

46 Ibidem. 
law relationship, that we do not deal with equal parity of parties, or this equality experiences a far-reaching limitation. This is mainly the case in consumer turnover. Under such a consumer agreement, the undoubtedly weaker position should be attributed to the consumer ${ }^{47}$ However, contrary to this de facto inequality of the parties, consumer agreements are not mentioned as an example of the implementation of a non-consensual form of shaping a civil law relationship.

The literature on the subject indicates that on the basis of civil law, when discussing the issue of conventional legal relations, too little attention is paid to the "mechanical" classification of both parties to the legal relationship of the obligatory type as authorized entities. ${ }^{48}$ The obligation relationship, which provides for equality of parties, understood as the implementation of equal interests of parties equal to each other, is often an unidentifiable definition of the essence of the civil liability relationship. In general, within the limits set out in civil law, as part of a contractual relationship, there will be more or less uneven satisfaction of the interest of one of the parties in the resulting legal relationship. The principle of freedom of contract does not prejudge the actual implementation of the element of compliance of declarations of intent of the parties to the contract. ${ }^{49}$ It is unacceptable to identify the concept of freedom of contract with the freedom of contracts. ${ }^{50}$ Therefore, the creators of the Tax Ordinance draft needlessly emphasize the question of the inability to balance (on the model of civil law) the party of the tax authority with the other party of the "tax agreement."

At this point, it is worth moving to analyze whether there are other legal regulations within the scope of financial law, tax law or criminal law (including procedural law), where a consensual method of settling a case or dispute resolution would be introduced. The example of criminal law will be referred to with a reason. The comparison of the manner in which the consensual method or effects of its use has been introduced makes sense only when this confrontation refers to the law system, where - as in tax law — the public interest plays a primacy over the private interest. Tax law is sometimes compared with criminal law, although there are no such links between these branches of law as in the case of administrative law and tax law. ${ }^{51}$ Criminal law (like tax law) belongs to the category of intrusive law. ${ }^{52}$

The issue of criminal and process agreements has been widely discussed in the doctrine. It is emphasized that currently for the criminal process, the growing importance of consensus modes can be defined as one of the current tendencies of

47 B. Gnela, Consumer Contract in Polish Civil and Private International Law, Warszawa 2013, p. 195.

48 Ibidem, p. 322.

49 Z. Radwański, op. cit., p. 115.

${ }^{50}$ Ibidem.

${ }^{51}$ R. Mastalski, "Economic and legal limits of taxation," [in:] Financial Law, eds. E. FojcikMastalska, R. Mastalski, Warszawa 2013, p. 166.

52 Ibidem. 
this law. At the same time, the mere agreement communication does not constitute novum in procedural criminal law, as evidenced by the existence of at least several institutions well-established in the consensual method already in the code ${ }^{53}$ of criminal procedure of $1969 .{ }^{54}$ However, structures such as conviction without trial or voluntary submission to punishment occur only in the current wording of the criminal procedural law. ${ }^{55}$

Agreements in Polish criminal-procedural law — in a broad sense - can be defined as a contract concluded in the course of criminal proceedings by the defendant, including a procedural body, which in exchange for the defendant's behavior specified in the agreement provides for a procedural decision more favorable to the accused in comparison with that he could expect without committing to a particular behavior. ${ }^{56}$ Legal solutions constituting a manifestation of a consensual way of dealing with criminal proceedings in no case should be equated with the Anglo-American "bargaining for admission." ${ }^{57}$

Another area of intrusive law, under which the consensual method was used, despite the dominance of the state interest, is the Fiscal Penal Code. ${ }^{58}$ It is not only in criminal proceedings that there is a need to develop institutions based on consensual methods of settling matters. This is also the case in offense proceedings or tax penal proceedings. ${ }^{59}$ The rules of the fiscal penal code regulate the construction of voluntary submission to responsibility. The voices raised in the doctrine have a special meaning on the background of the consideration. These comments relate to the need to modify the established regulation in order to prevent further "distortion" of the legal structure, which was supposed to be consensual in nature and in practice this consensus is limited. ${ }^{60}$ The analysis of the practical functioning of the communication platform between the financial authority and the perpetrator leads to the conclusion that the negotiation relationship between the financial authority and the perpetrator occurring in the course of the preparation proceedings (fiscal penal) is not carried out in an optimal manner. ${ }^{61}$

53 The Act of April 19, 1969 Penal Code (Journal of Laws of 1969 no. 13 item 94).

54 M. Rogacka-Rzewnicka, Opportunism and Legalism of Criminal Prosecution in the Light of Contemporary Transformations of the Criminal Process, Warszawa 2007, p. 361.

55 The Act of June 6, 1997 The Code of Criminal Procedure (Journal of Laws of 2018.1987, i.e. of 2018.10.17); see P. Głogowska, "Consensualism in repressive proceedings," [in:] Criminal Proceedings and Other Repressive Proceedings, ed. P. Czarnecki, Warszawa 2016, p. 121.

${ }^{56}$ S. Waltoś, “"Agreements' in the Polish criminal trial de lege lata and de lege ferenda," Państwo i Prawo 1998, no. 2, p. 38.

57 A. Ważny, Problems of the Amended Criminal Procedure, Kraków 2004, p. 249.

58 The Act of September 10, 1999 (Journal of Laws of 2018.1958, i.e. of 2018.10.15).

59 S. Głogowska, op. cit., p. 119.

${ }^{60}$ I. Zgoliński, Voluntary Submission to Responsibility in Fiscal Criminal Law, Warszawa 2011, p. 255.

${ }^{61}$ Ibidem. 
As can be seen not only in civil law, but also in administrative law and criminal law, there has been research on the consensual meaning of law and the possibility of shaping legal relations that assume the equality of the parties. This is important in the respect that in the last two mentioned branches of law, public interest plays a dominant role. Despite the primacy of public interest, there is an interest in the development of consensual forms of dealing with the matter and, at the same time, a clear attempt to preserve the non-arbitrary nature of such solutions. This is what is missing in the mere regulation of the "tax agreement." Meanwhile, the lack of striving to equalize the parties of the "tax agreement" seems to be pointless. At the same time, it would not have to be the equality of parties characteristic of civil law relations (although civil law rarely has a pure form of equality of the parties to the obligation relationship).

\section{Concluding remarks}

The regulation of non-governing forms of operation of tax authorities is the normative basis that determines the change in the way in which tax matters are dealt with. Without it, such a change is not possible. At the same time, it should be clearly stated that the regulation itself does not guarantee, does not determine, but creates a chance for it. Therefore, it is worth not wasting the opportunities or benefits which may be contributed to by the introduction of new constructions to tax law provided for by the provisions of the Tax Ordinance draft. The proposed legal constructions can set a milestone for tax law, dictated by the needs of the current and future socio-economic reality. That is why it is so important to consider whether tax law is not ready to go beyond the classic framework of the legal-tax relationship. This will minimize the risk of introducing regulations consisting of provisions dead in practice or the legislator being only an apparent manifestation of a qualitative change or the implementation of optimization principles.

At this point, it is fitting to present the most important de lege ferenda demands addressed to the legislator.

Above all, we should again refer to what was the essence of these considerations. Consensual handling of matters (including tax ones) has many advantages. Granting the tax authorities the possibility of using the proposed solution in the form of a "tax agreement" will make it possible to prevent further escalation of specific tax disputes by seeking a consensus. This will contribute to optimizing the efficiency, speed and simplicity of the settlement and the proceedings itself, saving time and money for both parties to disputes, increasing the efficiency of tax authorities, and relieving administrative courts. However, would the acceptance of the option, within which the tax authority by concluding a "tax agreement" would resign — at the moment of concluding such an agreement — from its 
position of a privileged entity, not constitute a more effective implementation of the consensual method of settling tax matters?

It is possible to assume that in relation to the relationship formed on the basis of the "tax agreement" between the tax authority and the taxpayer, the classic recognition of the supremacy relation of the tax authority will not be updated. If a regulation were introduced, in which at least at the level of procedural law and to a limited degree - the equality of the parties of the "tax agreement" would be allowed, the tax authorities would be burdened with the load of going beyond the classic framework of a tax-related relationship (as it would be an essentially privileged entity).

The author of the article in no way opts for the "tax agreement" to seek to treat the tax authority in a "non-tax" manner. The tax authority will continue to represent mainly the public interest by concluding and implementing provisions of "tax agreements." However, it is important to establish appropriate limits of consensus and equality of its parties within the framework of such a "tax agreement." The consensuality that the parties would strive for, should foster the pursuit of the private interest in the optimal dimension and, at the same time, would not affect the public interest. This is possible. In this way, the equality of parties manifests itself in the framework of consumer contracts (where the entrepreneur's party is stronger), or on the level of repressive law (for example, in criminal law - where, as indicated, the consensual way of settling the matter should not disqualify the aspiration to equalize the position of all participants of this consensus). In this respect, it is important, among others, that the tax authority in the decision on the refusal to conclude a "tax agreement" indicates detailed premises (factual and legal), which are the basis for refusal to conclude an agreement.

In addition, it is worth noting that the possibility of concluding a tax agreement is the implementation of the principle of amicable settlement of tax matters. According to the current wording of the provisions of the Tax Ordinance draft, a "tax agreement" can only be entered into if the doubts regarding the facts are updated. In these cases, a "tax agreement" would be a solution to excessive difficulties or costs in the process of determining the facts. As indicated in the explanatory memorandum to the Tax Ordinance draft, ${ }^{62}$ negotiations or amicable arrangements regarding the facts and the evidence proceedings also take place in the legal systems of other countries (an example - "Litigation and Settlement Strategy" of the British tax administration HMRC — Her Majesty's Revenue and Customs). ${ }^{63}$ Even if it is possible to go beyond the traditional

62 Justification of the draft of the Act - Tax Ordinance of 7.03.2019...

${ }^{63}$ In the invoked justification to the Tax Ordinance draft, an example of foreign regulation was referred, within which a legal structure similar to the analysed "tax agreement" was used — the document Resolving tax disputes - Commentary on the litigation and settlement strategy - access protocol: https://www.gov.uk/guidance/tax-disputes-alternative-dispute-resolution-adr (accessed: 10.10.2019). 
model of relations in the context of a legal-tax relationship, one should consider expanding the scope of the "tax agreement" that goes beyond the evidence proceedings.

The need to broaden the scope of the subject of the "tax agreement" cannot be omitted. According to the project, a party that is not a representative of the public interest would be limited to the taxpayer. This would mean omitting the payers, collectors or legal successors of taxpayers as part of the proposed solution. According to the author of this work, such a designation of the subjective scope of the "tax agreement" would unnecessarily limit its potential.

A change in the perception of the relationship of the "tax debtor - tax creditor" is necessary. A "dialog" should be allowed at least between the two entities of the tax-related relationship. The content of the statutory state of affairs defined in tax laws limits the possible cooperation of parties to the legal tax relationship, but does not reject the possibility of communication between these parties. Implementation of the equality of the parties - although to a minimal extent - should not pose a threat to the public interest. On the contrary - it can be a contribution to the development of optimal functioning of the whole tax system. Therefore, it may be invaluable to undertake detailed research on the consensual meaning of law in tax legislation.

\section{References}

Borszowski P., Elementy stosunku prawnego zobowiazania podatkowego [Elements of the Legal Relationship of Tax Liability], Kraków 2004.

Cieślik Z., Umowa administracyjna w państwie prawa [Administrative Agreement in the State of Law], Kraków 2007.

Etel L. (ed.), Ordynacja podatkowa. Kierunkowe założenia nowej regulacji [Tax Ordinance: Directional Assumptions of the New Regulation], Białystok 2015.

Gnela B., Umowa konsumencka w polskim prawie cywilnym i prywatnym międzynarodowym [Consumer Contract in Polish Civil and Private International Law], Warszawa 2013.

Głogowska S., "Konsensualizm w postępowaniach represyjnych" [Consensualism in repressive proceedings], [in:] Postepowanie karne a inne postepowanie represyjne [Criminal Proceedings and Other Repressive Proceedings], ed. P. Czarnecki, Warszawa 2016.

Mariański A., Rozstrzyganie watpliwości na korzyść podatnika. Zasada prawa podatkowego [Resolving Doubts in Favour of the Taxpayer: The Principle of Tax Law], Warszawa 2011.

Mastalski R., "Ekonomiczne i prawne granice opodatkowania" [Economic and legal limits of taxation], [in:] Prawo finansowe [Financial Law], eds. E. Fojcik-Mastalska, R. Mastalski, Warszawa 2013.

Mastalski R., Prawo podatkowe [Tax Law], Warszawa 2016.

Morawski L., "Spór o model polityki prawa - ujęcie systemowe" [The dispute over the model of legal policy - a systemic approach], Państwo i Prawo 1992, no. 9.

Morawski L., Wstęp do prawoznawstwa [Introduction to Jurisprudence], Toruń 1998.

Nita A., Porozumienie w prawie podatkowym [Agreement in Tax Law], Warszawa 2014.

Nowacki J., Prawo publiczne - prawo prywatne [Public Law — Private Law], Katowice 1992.

Ostojski P., Instrumentalizacja prawa o postępowaniu administracyjnym [Instrumentalization of the Law on Administrative Proceedings], Poznań 2017. 
Radwański Z., Teoria umów [Theory of Contracts], Warszawa 1977.

Rogacka-Rzewnicka M., Oportunizm i legalizm ścigania przestepstw w świetle wspótczesnych przeobrażeń procesu karnego [Opportunism and Legalism of Criminal Prosecution in the Light of Contemporary Transformations of the Criminal Proces], Warszawa 2007.

Waltoś S., "“Porozumienia' w polskim procesie karnym de lege lata i de lege ferenda ["Agreements" in the Polish criminal trial de lege lata and de lege ferenda], Państwo i Prawo 1998, no. 2.

Ważny A., Problemy znowelizowanej procedury karnej [Problems of the Amended Criminal Procedure], Kraków 2004.

Zacharenko L., "Umowa administracyjna (umowa publicznoprawna)" [Administrative agreement (public law contract)], [in:] Administracja. Prawo administracyjne. Część ogólna [Administration: Administrative Law. General Part], eds. J. Blicharz, L. Zacharenko, Katowice 2018.

Zgoliński I., Dobrowolne poddanie się odpowiedzialności w prawie karnym skarbowym [Voluntary Submission to Responsibility in Fiscal Criminal Law], Warszawa 2011.

Ziembiński Z., Problemy podstawowe prawoznawstwa [Basic Problems of Legal Studies], Warszawa 1980 .

Zimmermann J., Aksjomaty prawa administracyjnego [Axioms of Administrative Law], Warszawa 2013.

Żukowski L., [in:] L. Żukowski, R. Sawuła, Postępowanie administracyjne i postępowanie przed Naczelnym Sadem Administracyjnym [Administrative Proceedings and Proceedings before the Supreme Administrative Court], Warszawa 2002.

\section{Jurisdiction}

Judgment of the Supreme Court (until 2003.12.31) in Szczecin of 6 June 2001, SA/Sz 511/00, LEX 1693828.

Judgment of the Supreme Court of June 24, 2014, I CSK 431/13, LEX 1511100.

Judgment of the Supreme Court of June 28, 2017, IV CSK 511/16, LEX 2360534. 